\title{
RANCANG BANGUN SISTEM INFORMASI CATERING BERBASIS CUSTOMER RELATIONSHIP MANAGEMENT PADA RIA CATERING
}

\author{
${ }^{1}$ Mohd. Ilham Akbar Khoiri, ${ }^{2}$ Siti Monalisa \\ ${ }^{1,2}$ Program Studi Sistem Informasi Fakultas Sains dan Teknologi \\ Universitas Islam Negeri Sultan Syarif Kasum Riau \\ Jl. HR. Soebrantas No. 155 Simpang Baru, Tampan, Pekanbaru, Riau - Indonesia 28293 \\ email: ${ }^{1}$ mohd.ilham.akbar.khoiri@ students.uin-suska.ac.id, ${ }^{2}$ siti.monalisa@uin-suska.ac.id
}

\begin{abstract}
ABSTRAK
Ria Catering merupakan salah satu usaha daerah yang menyajikan masakan khas melayu. Dari segi produksi dibagi dalam 3 macam yaitu prasmanan, nasi kotak, kue kotak. Berdasarkan observasi yang telah dilakukan, saat ini sistem yang berjalan Ria Catering menerapkan dua metode yaitu pelanggan melakukan pemesanan makanan secara manual dan komputerisasi untuk pembuatan laporan. Metode yang digunakan dalam perancangan dan pengembangan sistem informasi ini adalah metode Object Oriented Analysis Design (OOAD) dengan penggunaan empat Diagram Unified Modelling Language (UML). Hasil yang diperoleh dari penelitian ini adalah sistem informasi catering berbasis Costumer Relationship Management (CRM). Sistem informasi ini nantinya dapat membantu pihak Ria Catering dalam memperoleh informasi atau data pemesanan yang dilakukan secara cepat
\end{abstract} dan mudah.

Kata Kunci: Costumer Relationship Management, Object Oriented Analysis Design, Ria Catering, Unified Modelling Language.

\section{A. PENDAHULUAN}

Dimasa saat ini kemajuan teknologi dan persaingan bisnis semakin ketat dengan banyaknya penjualan berbasis online dan media sosial sebagai media untuk mempromosikan produk. Hal ini menuntut suatu perusahaan untuk memiliki keunggulan kompetitif agar dapat bersaing dengan perusahaan lainnya. Bisnis selalu dipengaruhi oleh kebutuhan terhadap informasi untuk mendukung kinerja perusahaan dalam menghasilkan beberapa kebijakan, keputusan, serta strategi agar perusahaan mampu bersaing. Faktor keberhasilan perusahaan bukan hanya terletak pada produk yang ditawarkan, tetapi seberapa baik perusahaan tersebut memuaskan kebutuhan pelanggan dengan menjaga dan menjalin hubungan yang baik dengan pelanggan. Loyalitas (kesetiaan) pembeli merupakan aspek penting dalam lingkungan bisnis dan dapat menentukan keberlangsungan perusahaan tersebut. Selain memberikan keuntungan financial dalam jangka panjang, loyalitas pelanggan dapat membantu membangun citra yang positif bagi produk atau jasa yang ditawarkan.

Ria Catering merupakan salah satu usaha daerah yang menyajikan masakan khas melayu, untuk melayani: rapat, seminar, launching, aqiqah, sunatan, akad nikah dan resepsi pernikahan. Dari segi produksi dibagi dalam 3 macam yaitu prasmanan, nasi kotak, kue kotak. Mulai berdiri tahun 1985 dengan pengalaman lebih dari 25 tahun, telah melayani berbagai event tingkat daerah hingga nasional seperti berbagai kegiatan pemerintah kabupaten/kota hingga Provinsi Riau, kantor Walikota Pekanbaru, kantor Gubernur Riau, DPRD Provinsi Riau, MTQ tingkat Provinsi, POPDA Prov Riau, POSPEDA, PEPARNAS, hingga Pekan Olahraga Nasional. Beralamat jl utama/akasia no.78 Rejosari Telp. (0761) 32737 Fax. 21121 HP. 0811 760267, 0816 370176, 08117570350 PekanbaruRiau.

Berdasarkan observasi yang telah dilakukan, saat ini sistem yang berjalan Ria Catering menerapkan dua metode yaitu pelanggan melakukan pemesanan makanan secara manual dan komputerisasi dalam pembuatan laporan. Proses manual dengan pelanggan datang kasir memberikan daftar menu, setelah pelanggan menyebutkan pesanan dan tanggal pesanan diantarkan, kasir mencatat dibuku pesanan dan buku nota. Kemudian kasir menanyakan kepada pelanggan mau membayar DP atau bayar lunas, kasir memberikan bon, pelanggan menerima bon lunas atau DP kemudian pergi. Dan proses komputerisasi. Setelah pelanggan pergi kemudian kasir memindahkan salinan pesanan pelanggan ke komputer dan dibuat dalam Ms. Word dan Ms.Excel. Ms Word untuk laporan ke dapur, laporan berisi no, hari/tgl jam, menu, Qty pesanan kemudian diprint dan dikasihkan ke dapur untuk di proses pesanan makanan pelanggan. Sedangkan Ms.Excel untuk laporan bulanan dilaporan itu berisi tanggal pemesanan, nama, jumlah pesanan, harga perunit, dan total biaya. Penulis melihat kedua metode ini tidak efektif dan efisien karna membuat 
dua kali kerja. Dalam pemesanan Ria Catering hanya menerima lima order anter gantung jumlah pesanan, namun orderan tidak sampai lima dalam perharinya. Sebagai pemasaran Ria Catering melalui spanduk yang ditempel dipagar, brosur, mobil box yang ditempel stiker Ria Catering dan mengenalkan masakan pada saat pemilik Catering membuat acara. Metode pemasaran seperti ini belum terlalu efektif ditambah jaman sekarang sudah menggunakan teknologi buat pemasaran. Cangkupan dari pemasaran diatas tidak begitu luas,Proses pemesanan pelanggan datang langsung ke Ria Catering. dari segi pelanggan, pelanggan yang dimiliki oleh Ria Catering tidak bersifat tetap bisa berpindah ke Catering lain. pelanggan yang memesan bisanya orang yang pernah menggunakan jasa dari Ria Catering, saudara, atau rekan bisnis.

Salah satu strategi yang dapat diterapkan untuk mengatasi masalah diatas adalah dengan menggunakan metode Customer Relationship Management (CRM) yang digabungkan dengan teknologi. CRM merupakan suatu strategi perusahaan yang digunakan untuk memanjakan pelanggan agar tidak berpaling ke pesaing. Dalam hal ini perusahaan memberikan sentuhan pelayanan individual dengan memperlakukan pelanggan sebagai raja ${ }^{[1]}$. CRM merupakan filosofi bisnis yang menggambarkan suatu strategi penempatan client sebagai pusat proses, aktivitas dan budaya. Konsep ini telah dikenal dan banyak diterapkan untuk meningkatkan pelayanan di perusahaan ${ }^{[2]}$. CRM salah satu strategi yang digunakan untuk mengetahui kebutuhan konsumen dan juga untuk menarik, menjaga atau mempertahankan konsumen agar tetap dekat dengan perusahaan ${ }^{[3]}$.

Dengan dibangunnya E-CRM diharapkan dapat menjadi solusi perusahaan dalam pemensana, pemasaran, pelayanan terhadap pelanggan dan dapat memanfaatkan konten-konten yang akan dibangun seperti email advertising, sosial media seperti instagram, promo-promo, kritik dan saran untuk menjadikan masukan dan perbaikan perusahaan serta dapat mempermudah pelanggan untuk melakukan pemesanan secara online serta dapat diintergrasi kesistem pemasaran untuk Ria Catering. E-CRM telah berhasil digunakan dalam berbagai kasus seperti, menghasilkan sebuah sistem terkomputerisasi, berbasis web yang memberikan keunggulan dalam penyimpanan, pencarian data pelanggan yang akurat, penyampaian informasi tetang perusahaan dengan cepat, menerima masukan kritik dan saran dari pelanggan. Disisni sistem informasinya menerpakan $E-C R M$ yang mengelola data pelanggan, nantinya data tersebut akan menjadi acuan bagi perusahaan dalam mengembangkan usahanya $^{[4]}$. Menghasilkan sebuah sistem terkomputerisasi berbasis web yang dapat memudahkankan Catering Ummi Nisa dalam memberikan penawawaran setiap produk, memperoleh informasi mengenai barang yang ditawarkan dan memudahkan konsumen untuk memesan Catering yang ditawarkan namun data pelanggan yang didapat tidak dikelola lagi hanya fokus pada pemasaran ${ }^{[5]}$.

Berdasarkan penjelasan sebelumnya, maka dari itu penulis mengambil judul Tugas Akhir "Rancang Bangun Sistem Informasi Catering Berbasis Customer Relationship Management (CRM) Pada Ria Catering".

A. LANDASAN TEORI

\section{C.1 Object Oriented Analysis Design (OOAD)}

OOAD merupakan sebuah pendekatan untuk memikirkan suatu masalah dengan menggunakan model yang dibuat menurut konsep sekitar dunia nyata. Dasar pembuatannya adalah objek yang merupakan kombinasi antara struktur dasar dan perilaku dalam satu entitas. OOAD mencakup analisis dan desain sebuah sistem dengan pendekatan objek, yaitu analisis berorientasi objek (OOA) dan desain berorientasi objek (OOD). OOA adalah metode analisis yang memeriksa requirement (syarat/keperluan yang harus dipenuhi sebuah sistem) dari sudut pandang kelas-kelas dan objekobjek yang ditemui dalam lingkungan organisasi. Sedangkan OOD adalah metode untuk mengarahkan arsitektur software yang didasarkan pada manipulasi objek-objek sistem atau sub-sistem.

\section{C.2 Unified Modelling Language (UML)}

Unified Modelling Language (UML) adalah sebuah standar bahasa yang banyak digunakan di dunia industri untuk mendefinisikan requirement, membuat analisis dan desain, serta menggambarkan arsitektur dalam pemrograman berorientasi objek ${ }^{[6]}$.

\section{C.3 Model Waterfall}

Model SDLC air terjun (waterfall) sering juga disebut model sekuensi linier (sequenntial linear) atau alur hidup klasik (classic life cycle). Model air terjun menyediakann pendekatan alur hidup perangkat lunak secara sekuensial atau terurut dimulai dari analisis, desain, pengodean, pengujian, dan tahap pendukung (support) ${ }^{[7]}$.

\section{C.4 Costumer Relationship Management (CRM)}

CRM adalah kombinasi dari proses bisnis dan teknologi yang tujuannya untuk memahami pelanggan dari berbagai prospektif sebagai pembeda produk dan jasa perusahaan secara kompetitif ${ }^{[8]}$. Manajemen hubungan pelanggan merupakan proses keseluruhan yang digunakan membangun dan menjaga hubungan dengan pelanggan dengan memberikan nilai pelanggan superior dan kepuasan pelanggan ${ }^{[9]}$. Costumer Relationship Management (CRM) merupakan strategi dalam memperoleh, mengkonsolidasi, menganalisa data, yang kemudian 
digunakan dalam berinteraksi dengan customer, dengan demikian akan terbangun hubungan yang lebih baik dengan customer $^{[10]}$.

\section{B. METODOLOGI PENELITIAN}

Tahapan-tahapan yang dilakukan pada Tugas Akhir ini dapat dilihat pada Gambar 1. Penjelasan masing-masing tahapan akan dijelaskan pada subbab-subbab yang ada dalam Bab 3 ini.

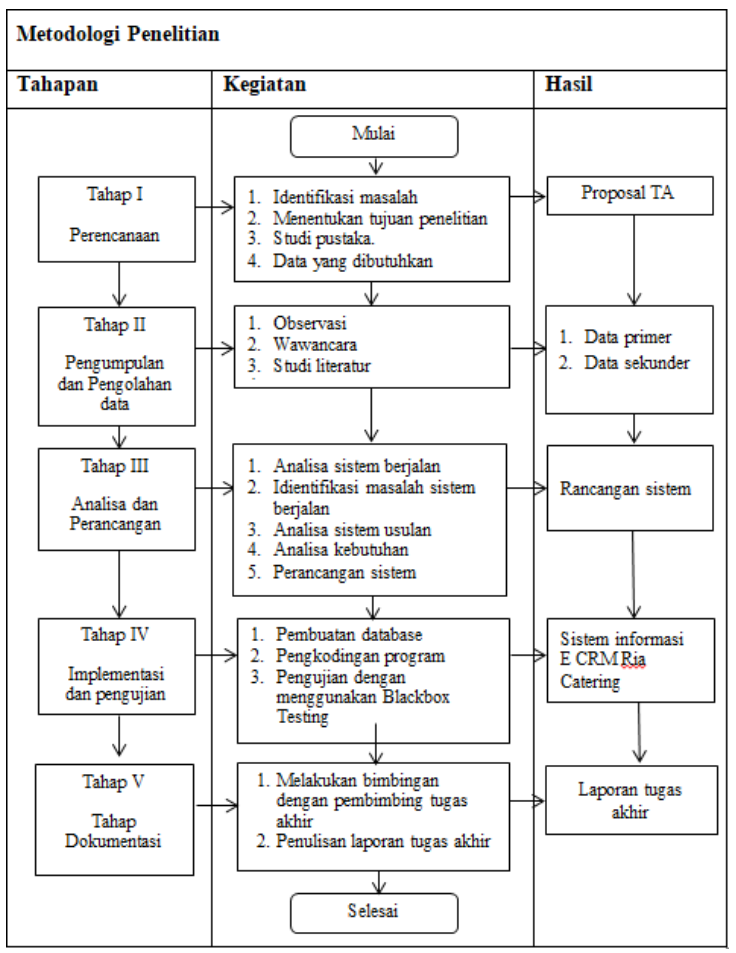

Gambar 1. Metodologi Penelitian

\section{C.1 Tahap Perencanaan}

Tahap perencanaan adalah tahapan yang wajib dan paling utama dilakukan dalam suatu penelitian. Adapun tahapan yang harus direncanakan dalam penelitian yaitu:

1. Menentukan studi kasus, wawancara awal, dan observasi.

Tahap perencanaan yang pertama harus dilakukannya itu menentukan studi kasus penelitian dan telah ditetapkan penelitian dilakukan pada Ria Catering. Selanjutnya melakukan wawancara, wawancara dilakukan dengan Bapak Tengku Darius selaku Direktur Umum. Selanjutnya melakukan observasi mengenai proses penjualan serta pemasaran yang dilakukan pada Ria Catering.

2. Identifikasi Masalah

Tahap perencanaan yang kedua yaitu mengidentifikasi masalah-masalah yang selalu terjadi. Identifikasi dilakukan dengan hal-hal yang berhubungan dengan proses pemasaran dan pemesanan yang sedang berjalan pada Ria Catering.

3. Merumuskan Masalah
Tahap perencanaan yang ketiga yaitu merumuskan masalah penelitian telah di dapat, apa saja masalah yang terjadi pada Ria Catering dan merumuskan masalahnya yaitu bagaimana merancang dan membangun sistem infomasi Catering berbasis CRM pada Ria Catering.

4. Menentukan Judul

Tahap perencanaan yang keempat yaitu menentukan judul penelitian setelah didapat masalah penelitian maka dapat disimpukan judul penelitianya itu Rancang Bangun Sistem Infomasi Catering Berbasis Costumer Relationship Management (CRM) pada Ria Catering.

\section{C.2 Tahap Pengumpulan Data}

Pada tahap pengumpulan data bertujuan untuk lebih mengetahui mengenai permasalahan yang diteliti. Dari data yang dikumpulkan akan dapat diketahui mengenai proses penjualan dan pemasaran yang terjadi pada saat ini. Data-data dapat diperoleh melalui wawancara langsung dan dengan cara melihat langsung dilapangan proses pemasaran dan penjualan yang terjadi. Dalam hal ini objek penelitian adalah Ria Catering. Hal yang dapat dilakukan untuk mendapatkan data yang dibutuhkan dalam penelitian ini adalah:

1. Wawancara

Dalam penelitian ini penulis menggunakan metode pengumpulan data wawancara tidak terstruktur. Peneliti bertatap muka langsung dengan narasumber yaitu Bapak Tengku Darius sebagai Direktur Umum. Peneliti mengajukan pertanyaan-pertanyaan secara langsung seperti bagaimana sejarahnya, prosedur pemesanan dan pemasaran, apakah pernah terjadi kesalahan dalam pemesanan, serta adakah permasalahan dalam pemasaran. Wawancara ini bertujuan untuk mengetahui lebih jelas permasalahan yang terjadi dalam proses layanan pada Ria Catering.

2. Observasi

Meneliti profil organisasi yang membahas tentang, visi, misi, dan tujuan yang akan menjadi dasar untuk proses analisa dan menemukan solusi dari permasalahan yang terjadi saat proses pemesanan dan pemasaran pada Ria Catering. Melihat serta meneliti proses pemesanan dan pemasaran yang berjalan pada Ria Catering.

3. Studi Literatur

Menggunakan literatur yang telah ada seperti jurnal-jurnal pendukung dan buku untuk digunakan sebagai referensi atau bahkan digunakan sebagai bahan pembanding. Contoh jurnal yang diambil yakni "pengolahan bisnis Catering ummi nisa medan berbasis Web" yang di susun oleh Khairunnisa, Damayanti pada tahun 2018, dan jurnal "penerapan Customer Relationship Management (CRM) 
berbasis Web (studi kasus pada sistem informasi pemasaran di toko yen-yen) yang di susun oleh dyantina, farina, dan ibrahim pada tahun 2012. Contoh buku yang diambil salah satunya adalah "rekayasa perangkat lunak terstruktur dan berorientasi objek" yang dikarang oleh Rosa A.S M. Shalahuddin pada Tahun 2015.

\section{C.3 Tahap Analisa dan Perancangan}

Tahap analisa dan perancangan merupakan tahap ketiga dalam mengerjakan laporan tugas akhir yang mana nantinya akan ada beberapa tahap yang dikerjakan mulai dari yang pertama yaitu menganalisa sistem yang sedang berjalan, kedua desain sistem yang akan dibangun, ketiga desain UML, keempat desain basis data, kelima desain tampilan sistem. Adapun penjelasannya sebagai berikut:

1. Menganalisa Sistem yang Sedang Berjalan Tahap analisa dan perancangan yang pertama yaitu menganalisa sistem yang sedang berjalan menganalisa seluruh kegiatan yang dilakukan dalam proses pemesanan dan pemasaran pada Ria Catering dengan menggunakan metode pengembangan Waterfall dan OOAD.

2. Desain sistem yang akan di bangun Tahap desain ini menggambarkan bagaimana rancangan sistem yang akan dibangun sesuai kebutuhan dan fungsinya.

3. Desain UML

Tahap analisa dan perancangan yang kedua yaitu merancang UML dengan tools yang digunakan dalam UML yaitu use case diagram, activity diagram, dan class diagram.

4. Basis data

Tempat yang nantinya data akan disimpan dan memudahkan informasi dapat diperoleh dengan cepat.

5. Desain Tampilan Sistem

Tahap analisa dan perancangan yang kelima yaitu merancang tampilan sistem melakukan perancangan tampilan antarmuka yang akan dibangun sesuai dengan kebutuhan.

\section{C.4 Tahap Implementasi}

Tahapan ini di lakukan dengan tujuan untuk menjamin sistem yang dibuat sesuai dengan hasil dari analisis dan perancangan serta menyimpulkan bahwa sistem tersebut sesuai dengan yang di harapkan.

\section{C.4.1 Implementasi Sistem}

Tahap Implementasi adalah tahap dimana pembangunan sistem informasi Ria Catering mulai dilaksanakan. Pembangunan sistem dilakukan menggunakan beberapa aplikasi pendukung yaitu:
PHP dan MySQL, Notepad++, Javascript, dan HTML.

\section{C.4.2 Pengujian Sistem}

Pada tahap ini, sistem yang telah selesai dibangun akan di uji coba. Tujuannya untuk menjamin sistem yang dibangun sesuai dengan apa yang diharapkan. Pengujian sistem dilakukan dengan metode blackbox, yaitu: proses uji sistem ditampilkan dalam bentuk tabel yang didalamnya menjelaskan tentang deskripsi pengujian, kondisi awal, prosedur pengujian, data input yang digunakan, output yang diharapkan, kriteria evaluasi hasil, hasil yang didapat dan kesimpulan pengujian.

\section{C.5 Tahap Dokumentasi}

Tahap dokumentasi merupakan tahapan dalam membuat laporan penelitian dari awal hingga akhir. Tahapan dokumentasi terdiri dari tiga tahap yaitu sebagai berikut:

1. Melakukan konsultasi dengan pembimbing penelitian. Konsultasi pada pembimbing sangat diperlukan oleh penulis dalam memberikan saran dalam perbaikan pembuatan laporan penelitian.

2. Melengkapi laporan dan data penelitian dari awal hingga akhir.

\section{HASIL DAN PEMBAHASAN \\ D.1 Analisa \\ D.1.1 Analisa Sistem Berjalan.}

Berdasarkan wawancara kepada pemilik Ria Catering mengenai proses penjualan selama ini masih manual dalam mencatat pesanan makanan kedalam buku dan kwitansi. Sedangkan laporan pesanan buat mading dan laporan penjualan sudah komputerisasi, dalam pemesanan Ria Catering hanya menerima orderan lima pelanggan dalam satu hari namun orderan tidak sampai lima dalam tiap harinya dan proses pemesanan harus konfirmasi lima atau tiga hari sebelum hari acara. selanjutnya promosi masih mengandalkan cara lama dengan brosur/daftar menu, sepanduk, mobil box yang di cat/ditempel dengan logo ria Catering, pelanggan yang memesan rata-rata orang yang sudah pernah menggunkan jasa Ria Catering. Sehingga metode seperti ini belum efektif dan efisien karna ini hanya akan memakan banyak kertas, sepanduk, biaya airbrush/cutting apa lagi di jaman skarang orang sudah banyak mengandalkan tekhnologi dalam pemasaran.

Beberapa kekurangan sistem berjalan, yaitu: Pelanggan langsung datang ke Ria Catering, Pelanggan melihat brosur/daftar menu kemudian menyebutkan makanan dan tanggal acara ke kasir, Kasir mencatat pesanan makanan, tanggal acara ke bon dan buku pesanan. kemudian kasir menanyakan bayar lunas atau Dp Setelah pelanggan membayar diberi bon bukti pesanan dan pergi, kasir mengetik pesanan kedalam komputer dengan format Ms. 
Word (hari/tanggal jam, menu, qty), di print dan di tempel kemading, Bagian swalayan melihat pesanan yang ada di mading dan membeli apa-apa saja yang dibutuhkan oleh bagian dapur kemudian di proses, Selanjutnya kasir menginputkan kembali kedalam MS. Excel untuk di jadikan sebagai laporan bulanan (no, hari tanggal, nama konsumen, menu, qty, harga satuan, jumlah, total, lunas) ini membuat pengerjaan menjadi kurang efektif, sebaiknya dilakukan sekaligus.

Setelah masakan jadi bagian driver dan staf lapangan pergi kelokasi acara dan melayani pelanggan dengan menyiapkan meja, makanan, minuman, dan membersihkan sampah, (tergantung permintaan) acara selesai driver memberikan bukti tanda terima dan driver beserta staf lapangan kembali ke Ria Catering. Untuk lebih jelasnya dapat dilihat pada Gambar 2.

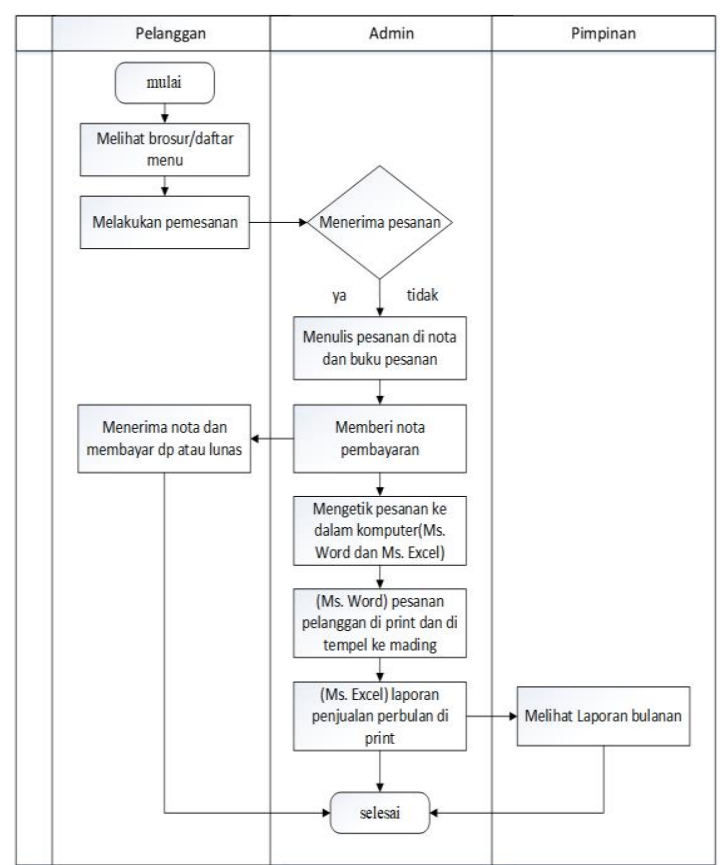

Gambar 2. Flowchart Sistem Berjalan

\section{D.1.2 Analisa Sistem Usulan}

Sistem usulan yang dibangun adalah sistem pemesanan yang digunakan oleh pelanggan untuk mememesan makanan tanpa perlu langsung datang ke Ria Catering, sekaligus memudahkan pelanggan melihat informasi menu-menu dan promo-promo apa saja yang ada pada Ria Catering, pelanggan juga dapat memberi kritik dan saran. Selain itu memudahkan kasir dalam porses pemesanan dan pembuatan laporan, Kemudian membantu dalam mendapatkan pelanggan baru dengan memanfaatkan teknologi seperti website, media social instagram, facebook dan whatsApp, dan nantinya sistem pemesanan yang dibangun akan menjadikan pelanggan sebagai member sehingga terjalin hubungan dengan pelanggan sesuai dengan konsep E-CRM. Sebelum pelanggan menggunakan sistem informasi Ria Catering, admin sistem akan melakukan login terlebih dahulu kemudain menginputkan data makanan (prasmanan, nasi kotak, pondok, kue, makanan, minuman, dan aqiqah) dan promo-promo, promo yang diberikan potongan harga $5 \%-20 \%$, contoh potongan $5 \%$ pemesanan bulan mei dengan sayarat dan ketentuan 200 porsi keatas).

Setelah admin selesai menginputkan data barulah pelanggan dapat melakukan pemesan makanan atau minuman yang ada disistem. Sebelum memesan pelanggan harus mendaftarkan diri terlebih dahulu, dengan mengisi biodata nama lengkap, email, username, password, tanggal lahir, nomer handphone, dan alamat. Setelah terdaftar pelanggan login ke halaman beranda, diberanda berisi info tetentang Ria Catering (menu favorit, promo-promo, pelayanan yang diberikan, syarat dan ketentuan, dan informasi kontak, media social Ria Catering), saat pelanggan ingin melakukan pesanan pilih kategori menu dan klik salah satu kategori yang diinginkan (prasmanan, nasi kotak, pondok, kue, makanan, minuman, dan aqiqah).

Setelah muncul dihalaman kategori menu yang dipilih, pilih menu dan isi jumlah pesanan yang di inginkan dan klik pesan. Kemudian pesanana tadi akan tersimpan kedalam keranjang jika kita ingin menambah pesanan tinggal pilih kategori menu, jika tidak lanjutkan proses pemesanan dengan mengisi tanggal acara, keterangan (jika ada), dan promo (jika ada), kemudian klik checkout dan muncul di halaman pesanan di halaman pesanana ini kita diminta untuk menginputkan jumlah DP atau jumlah bayar lunas dan diminta juga untuk menginputkan bukti trasnfer dan klik kirim. Selanjutnya admin melakukan verifikasi dengan melihat bukti transfer yang dikirim oleh pelanggan kemudian admin klik verifikasi dan order selesai. Selanjutnya admin mencetak pesanan dan menempelkanya dimading agar diproses oleh bagian dapur dan diantar setelah masakan diproses. Untuk lebih jelasnya dapat dilihat pada Gambar 3. 


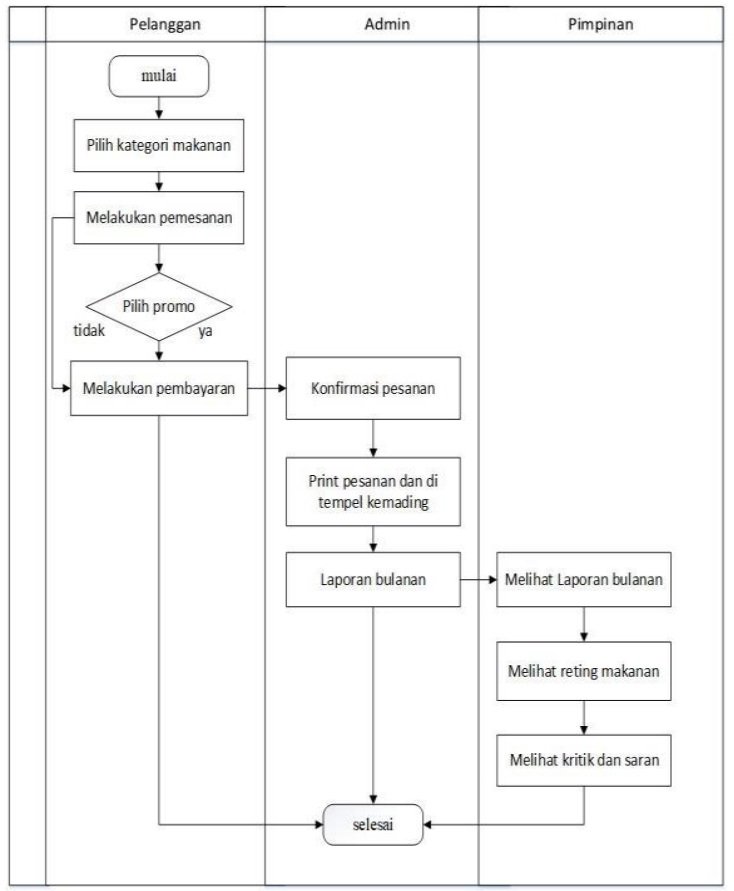

Gambar 3. FlowchartSistem Berjalan

\section{D.2 Kebutuhan Fungsional Aplikasi}

\section{Usecase Diagram.}

Diagram Usecase adalah diagram yang menggambarkan interaksi antara actor dengan aplikasi. Dalam usecase sistem informasi pemesanan Ria Catering terdapat 3 actor yaitu admin, pimpinan dan pelanggan. Berikut merupakan gambaran sistem dalam bentuk usecase diagram terlihat pada Gambar 2

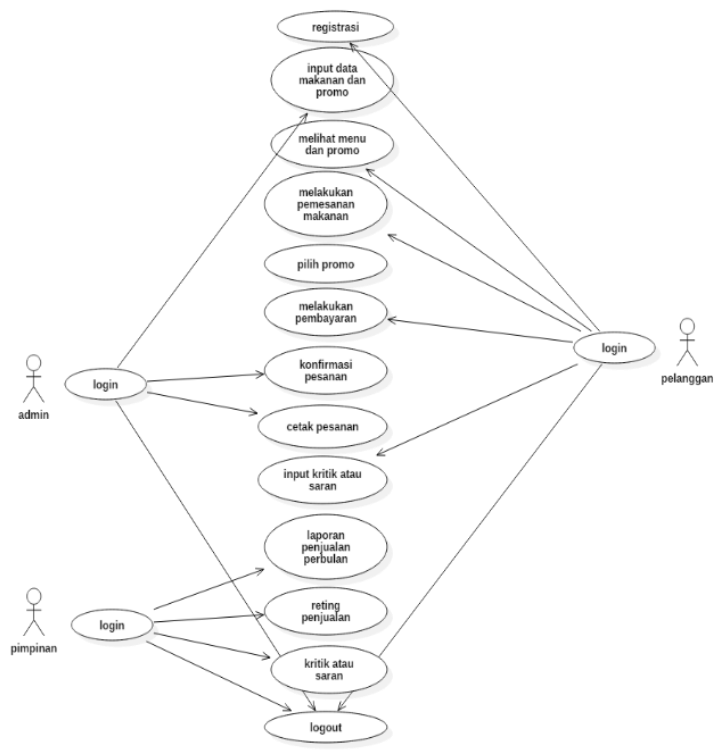

Gambar 4. Usecase Diagram Aplikasi Usulan

\section{E. IMPLEMENTASI DAN PENGUJIAN SISTEM \\ E.1 Implementasi Aplikasi \\ Tahapan ini merupakan tampilan hasil}

implementasi perancangan antarmuka (interface) yang telah dibuat. Berikut merupakan tampilan antarmuka aplikasi dengan 1 aktor yang terlibat.

\section{Tampilan alur penggunaan Sistem informasi pemesanan Ria Catering.}
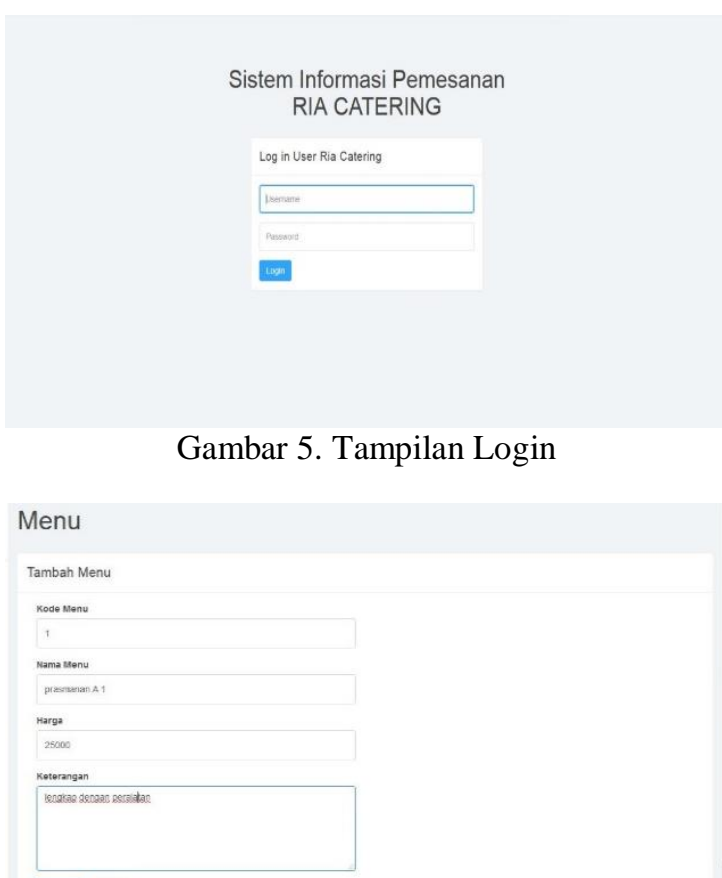

Gambar 6. Tampilan menu input

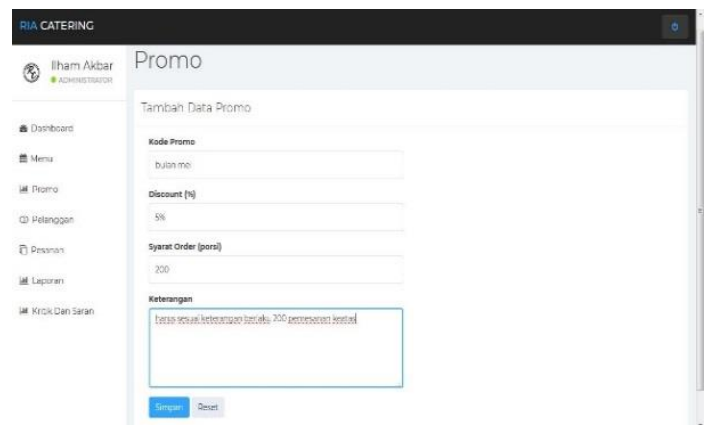

Gambar 7. Tampilan input promo

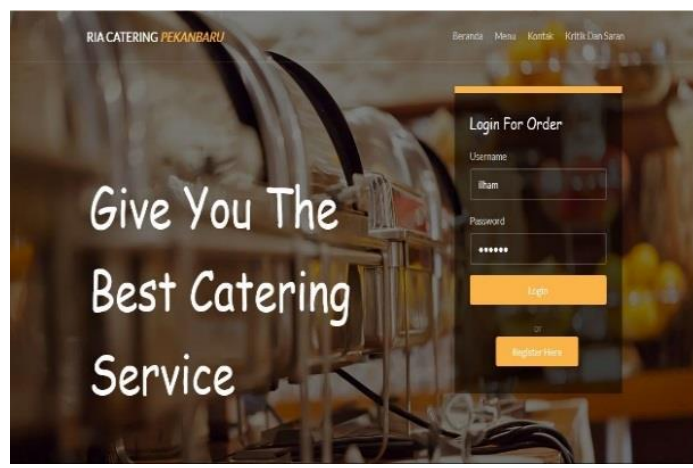

Gambar 8.Tampilan login pelanggan 
Jurnal Ilmiah Rekayasa dan Manajemen Sistem Informasi, Vol. 5, No. 2, Agustus 2019, Hal. 145-152 e-ISSN 2502-8995 p-ISSN 2460-8181

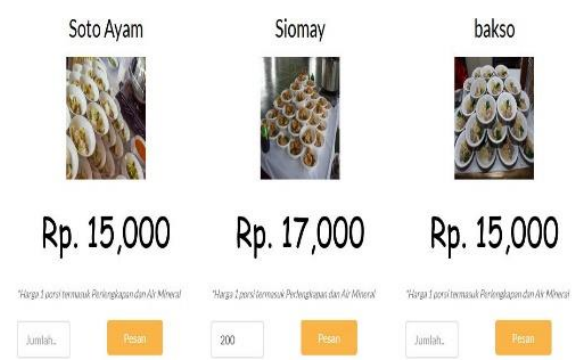

Gambar 9. Tampilan pemesanan makanan.

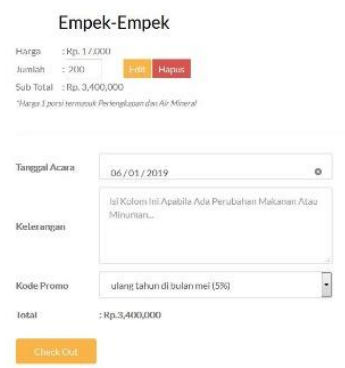

Gambar 10. Tampilan keranjang

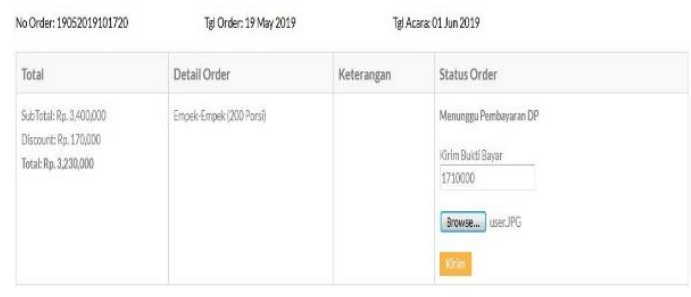

Ganbar 11. Tampilan pesanan

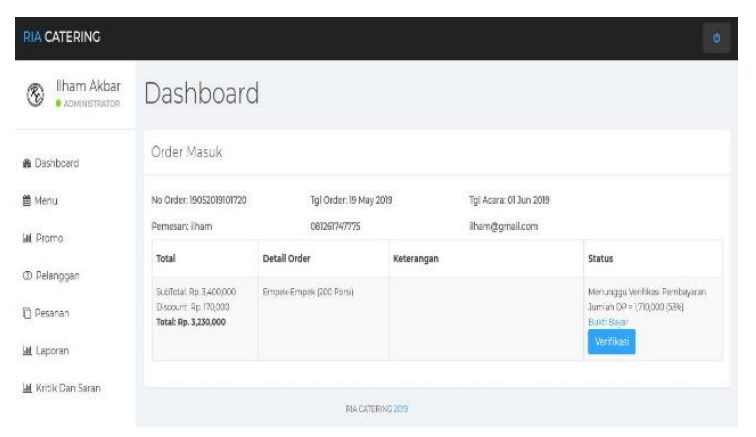

Gambar 12. Tampilan verifikasi

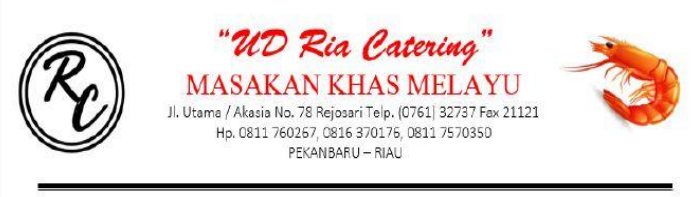

Data Pesanan Tagggal 2019-05-18 sampai 2019-05-18

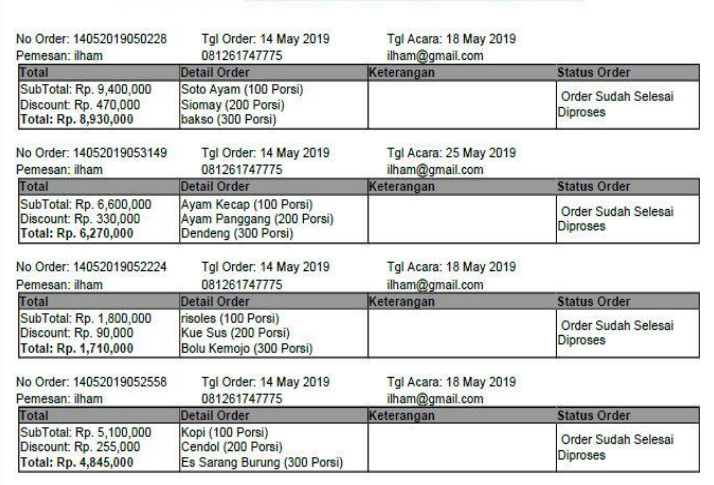

Gambar 13. Tampilan cetak pesanan

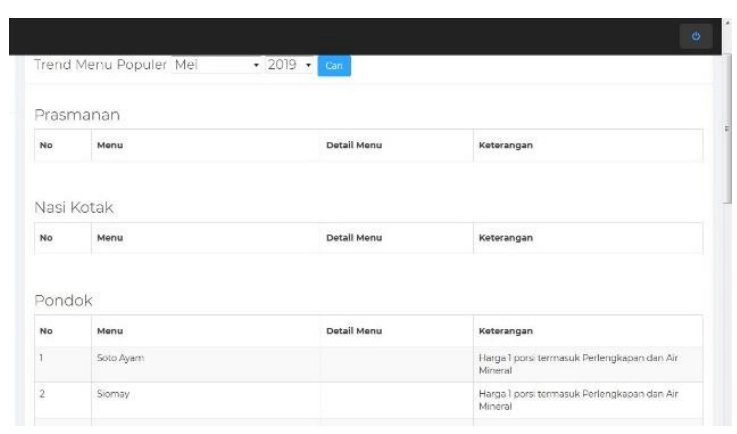

Gambar 14. Tampilan halaman reting

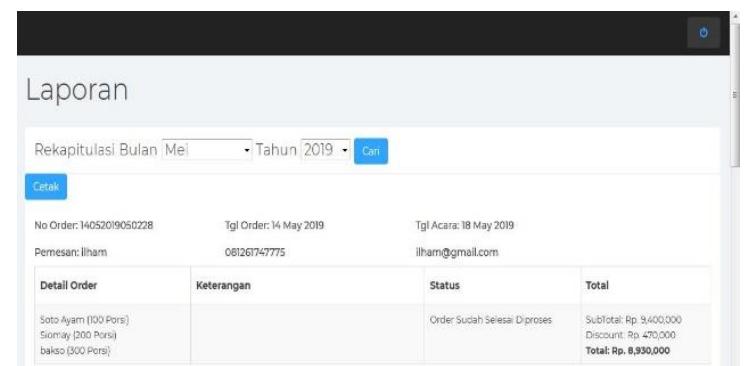

Gambar 15. Halaman tampilan laporan

Kritik Dan Saran

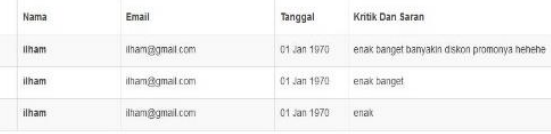

Gambar 16. Halaman tampilan kritik dan saran 


\section{E.2 Pengujian Aplikasi}

Sebelum program diterapkan terlebih dahulu aplikasi harus bebas dari kesalahan-kesalahan. Untuk itu program harus di uji terlebih dahulu untuk menentukan kesalahan-kesalahan yang mungkin terjadi. Pengetesan atau pengujian aplikasi ini dilakukan dengan teknik pengujian Black box (Black box testing) dan User Acceptance Test (UAT).

\section{Black Box Testing}

Tabel 7. Hasil pegujian black box testing

\begin{tabular}{|l|c|c|c|}
\hline \multicolumn{4}{|c|}{ Hasil black box aplikasi klasifikasi jurusa } \\
\hline Nama & Berhasil & Gagal & $\begin{array}{l}\text { Tingkat } \\
\text { Keberhasilan }\end{array}$ \\
\hline $\begin{array}{l}\text { Google } \\
\text { Chrome }\end{array}$ & 11 & 0 & $100 \%$ \\
\hline $\begin{array}{l}\text { Mozila } \\
\text { Firefox }\end{array}$ & 11 & 0 & $100 \%$ \\
\hline Opera & 11 & 0 & $100 \%$ \\
\hline $\begin{array}{l}\text { Microsoft } \\
\text { Edge }\end{array}$ & 11 & 0 & $100 \%$ \\
\hline Safari & 11 & 0 & $100 \%$ \\
\hline Rata-rata tingkat keberhasilan & $100 \%$ \\
\hline
\end{tabular}

\section{F. KESIMPULAN DAN SARAN}

\section{D.1 Kesimpulan}

Berdasarakan dari hasil analisa data pada bab sebelumnya, diperoleh bebrapa kesimpulan, yaitu:

Kesimpulan dari penelitian ini adalah:

1. Setelah merancang dan membangun sistem informasi Ria Catering maka kinerja dari staf di bagian kasir menjadi lebih cepat dan dapat mempermudah admin kasir dalam proses pemesanan dan pembutan laporan bulanan.

2. Dengan adanya sistem informasi sentra pelayanan dapat memudahkan pelanggan dalam memesan makan sehingga pelanggan dapat memesan di mana saja asalkan terhubung jaringan, dan menghemat waktu pada saat memesan makana.

3. Sistem ini menghasilkan berupa laporan pesanan, laporan bulan, reting makan yang paling di minati dan membangun hubungan jangka panjang antara pelanggan dan Ria Catering.

\section{D.2 Saran}

Berdasarkan kesimpulan yang telah disampaikan diatas, maka penulis menyarankan dan merekomendasikan beberapa hal sebagai berikut:

1. Kedepannya sistem informasi ini dapat diterpkan oleh Ria Catering agar dapat mempemudah kinerja Ria Catering

\section{REFERENSI}

[1] Jogiyanto, HM. 1995. Analisis \& Disain Sistem Informasi. Penerbit ANDI Offset, Yogyakarta.

[2] Kadir, Abdul. 2003. Pengenalan Sistem Informasi. Yogyakarta: Andi.

[3] Kalalo, E. Rinny. "Customer Relationship Management dan Kualitas Pelayanan Pengaruhnya Terhadap Loyalitas Konsumen PT. MATAHARI DEPT. STORE, MANADO". JURNAL UNIVERSITAS SAM RATULANGI MANADO. ISSN 2303-1174.

[4] Pijoh, k shinta. "Penerapan Customer Rrelationship Management, Personal Selling Dan Service Quality Terhadap Kepuasan Nasabah ASTRA KREDIT COMPANY MANADO”. JURNAL UNIVERSITAS SAM RATULANGI MANADO. ISSN 2303-1174.

[5] Ali ibrahim dan mira afrina. "Rancang Bangun Electronic Costumer Relationship Management (E-CRM) Sebagai Sistem Informasi Dalam Peningkatan Layanan Perpustakaan Digital Fakultas Ilmu Komputer Unsri”. JURNAL Jurusan Sistem Informasi Fakultas Ilmu Komputer Unsri. VOL. 5, NO. 2, Oktober 2013. ISSN 2355-4614.

[6] Ibrahim, ali. dkk "Penerapan Customer Relationship Management (CRM) Berbasis Web (Studi Kasus Pada Sistem Informasi Pemasaran di Toko YEN-YEN)". Jurnal Sistem Informasi (JSI), VOL. 4, NO. 2, Okotober 2012. ISSN 2355-4614.

[7] Deitel, P., \& Deitel, H. Java How To Program Edisi Kesembilan United States. Prentince Hall. 2012.

[8] Sidik, I. B. Pemrograman WEB dengan HTML. Bandung: Informatika. 2012.

[9] Kustiyahningsih, Yani \& Anamisa, Devie Rosa. 2011. PEMOGRAMAN BASIS DATA BERBASIS WEB MENGGUNAKAN $P H P \& M y S Q L$. Yogyakarta:Graha Ilmu.

[10] Sutedjo, Budi. dkk I-CRM Membina Relasi dengan Pelanggan.com. Yogyakarta: ANDI. 2003. 